\title{
Relationships Between Salinity and Short-Term Soil Carbon Accumulation Rates from Marsh Types Across a Landscape in the Mississippi River Delta
}

\author{
Melissa M. Baustian ${ }^{1}$ • Camille L. Stagg ${ }^{2}$ - Carey L. Perry ${ }^{3,4}$ • Leland C. Moss ${ }^{1}$. \\ Tim J. B. Carruthers ${ }^{1} \cdot$ Mead Allison ${ }^{1,5}$
}

Received: 20 May 2016 / Accepted: 16 December 2016/Published online: 6 January 2017

(C) The Author(s) 2017. This article is published with open access at Springerlink.com

\begin{abstract}
Salinity alterations will likely change the plant and environmental characteristics in coastal marshes thereby influencing soil carbon accumulation rates. Coastal Louisiana marshes have been historically classified as fresh, intermediate, brackish, or saline based on resident plant community and position along a salinity gradient. Short-term total carbon accumulation rates were assessed by collecting 10 -cm deep soil cores at 24 sites located in marshes spanning the salinity gradient. Bulk density, total carbon content, and the short-term accretion rates obtained with feldspar horizon markers were measured to determine total carbon accumulation rates. Despite some significant differences in soil properties among marsh types, the mean total carbon accumulation rates among marsh types were not significantly different (mean \pm std. err. of $190 \pm 27 \mathrm{~g}$ $\mathrm{TC} \mathrm{m}^{-2}$ year $^{-1}$ ). However, regression analysis indicated that mean annual surface salinity had a significant negative relationship with total carbon accumulation rates. Based on both analyses, the coastal Louisiana total marsh area $(1,433,700 \mathrm{ha})$ accumulates about 2.7 to $3.3 \mathrm{Tg} \mathrm{C} \mathrm{year}^{-1}$.
\end{abstract}

Melissa M. Baustian

mbaustian@thewaterinstitute.org

1 The Water Institute of the Gulf, One American Place, 301 Main St, Ste 2000, Baton Rouge, LA 70825, USA

2 U.S. Geological Survey, Wetland and Aquatic Research Center, 700 Cajundome Blvd, Lafayette, LA 70506, USA

3 Gulf South Research Corporation, 8081 Innovation Park Drive, Baton Rouge, LA 70820, USA

4 Coalition to Restore Coastal Louisiana, 6160 Perkins Road, Ste. 225, Baton Rouge, LA 70808, USA

5 Department of Earth \& Environmental Sciences, Tulane University, New Orleans, LA 70118, USA
Changing salinities due to increasing relative sea level or resulting from restoration activities may alter carbon accumulation rates in the short term and significantly influence the global carbon cycle.

Keywords Soil · Organic matter · Carbon accumulation · Salinity $\cdot$ Wetland $\cdot$ Louisiana

\section{Introduction}

Wetlands significantly impact the global carbon cycle because they contain 20-25\% of the world's soil organic carbon pool (Roulet 2000; Mitra et al. 2005). Carbon accumulation in marsh soils is an important ecosystem process that contributes to the burial of carbon, also known as "blue carbon" (Chmura et al. 2003; Mitra et al. 2005; Hopkinson et al. 2012). These carbon accumulation dynamics in marsh soils will likely be altered in response to future environmental conditions driven by climate change and coastal restoration activities. For example, it is predicted that as air and sea temperatures increase, some herbaceous wetland vegetation will be replaced with tropical woody mangrove species (Comeaux et al. 2012; Osland et al. 2012; Doughty et al. 2015) and that these community shifts may influence carbon production and accumulation rates in wetland soils. Sea-level rise is also predicted to produce more saline environmental conditions that could drive transitions of fresh marshes to more saline marsh types (Herbert et al. 2015) or drive salt marsh transgression inland (Kirwan et al. 2016). In addition, large-scale restoration projects could introduce more fresh water to some estuaries, resulting in fresher marsh types (Morris et al. 2013).

Coastal marshes depend on the burial of organic matter for their vertical accretion to help keep pace with sea-level rise (Reed 1995; Neubauer 2008; Nellemann and Corcoran 2009; 
McLeod et al. 2011). Marsh vegetation influences accretionary processes by contributing autochthonous carbon to the soil and enhancing sediment trapping of allochthonous particulate carbon mineral sediment and deposition with their stems (Morris et al. 2002; Baustian et al. 2012). Accretion is commonly measured via marker horizons, such as feldspar, and particle-reactive radiotracers, such as ${ }^{7} \mathrm{Be},{ }^{137} \mathrm{Cs}$, and ${ }^{210} \mathrm{~Pb}$ (Callaway et al. 1996; Taylor et al. 2013). These methodologies are complementary: feldspar marker horizons measure accretion on a short time scale, months to years, (Cahoon and Turner 1989; Bianchette et al. 2015) whereas ${ }^{137} \mathrm{Cs}$ and ${ }^{210} \mathrm{~Pb}$ measure accretionary processes over decadal timescales to a century or more (Delaune et al. 1978). Primary production processes dominate over decomposition processes in the surface layers (top $\sim 10 \mathrm{~cm}$ ) of the wetland soil column, which significantly influences the accumulation of organic matter and carbon content of marsh soils (Hatton et al. 1983; Nyman et al. 2006; Turner et al. 2006). Most of the root system for these species is concentrated in the upper $10 \mathrm{~cm}$ of the soil column (Gallagher et al. 1984); therefore, these short-term biological (e.g., production, decomposition) and physical (e.g., erosion, bioturbation) processes, which overall influence short-term carbon accumulation rates (Hansen and Nestlerode 2014), are captured by feldspar horizon methodologies.

Short-term carbon accumulation rates in marsh habitats depend mainly on the net balance of primary production and microbial decomposition (Odum et al. 1984; De Deyn et al. 2008). Both production and decomposition of organic matter are influenced by biological drivers and environmental conditions. Environmental conditions in surface waters and soil pore water, including salinity, temperature, inorganic nutrients, mineral sediment, and inundation frequency, can strongly influence organic matter accumulation in wetland soils (Valiela et al. 1976; Morris and Bradley 1999; Craft et al. 2002; Turner 2004; Marín-Spiotta et al. 2014). Salinity is an important factor in structuring coastal wetland communities and influences biogeochemical pathways (Craft 2007; Craft et al. 2009; Neubauer and Craft 2009). For example, increasing salinity can increase the concentration of terminal electron acceptors (such as iron, manganese and sulfate) that can increase microbial mineralization of organic matter and thus could result in a reduction in carbon accumulation (Herbert et al. 2015). Therefore, better understanding of how these environmental conditions influence carbon accumulation rates in various coastal wetland types is needed to predict how climate change through sea-level rise and future coastal restoration actions will influence the carbon accumulation rates (Markewich et al. 2007; Couvillion et al. 2013). In addition, these results may help support wetland restoration and management activities for carbon storage/burial capabilities and carbon credits (McLeod et al. 2011; Callaway et al. 2012; Hansen and Nestlerode 2014).
We hypothesized that short-term carbon accumulation rates varied along a gradient of increasing salinity. The objective of the present study was to examine the short-term total carbon accumulation rates in four marsh types across a salinity gradient in coastal Louisiana. We addressed the following questions: 1) how do short-term total organic carbon accumulation rates differ among marsh types in coastal wetlands, and 2) how do the environmental conditions influence the total organic carbon accumulation rates in these marsh types?

\section{Methods}

\section{Site Description}

A total of 24 marsh sites were selected for this study in the Mississippi and Atchafalaya delta regions of Louisiana within four marsh types. We defined marsh types based on plant community composition and salinity values (sensu Visser et al. 2002). Each marsh type (fresh, intermediate, brackish, and saline, Chabreck 1972) was associated with a particular salinity range (Cowardin et al. 1979; Odum 1984). However, because multiple factors influence the distribution of marsh plants, and many species occur over a wide range of salinity conditions, some sites may exist outside of the defined salinity range for a particular wetland type. Six sites each were sampled within four marsh types: fresh, intermediate, brackish, and saline (Odum et al. 1984; Visser et al. 1998) spanning two hydrologic basins, Terrebonne and Barataria (Fig. 1). Dominant vegetation included: Panicum hemitomon and Typha latifolia at fresh marshes, Sagittaria lancifolia and Scheonoplectus americanus at intermediate marsh types, Spartina patens and Scheonoplectus americanus at brackish marsh types, Spartina alterniflora and Juncus romerianus at saline marsh types. The 24 sites, which have been characterized in previous ecological studies (Stagg et al. 2016) encompassed a relatively broad geographical landscape $(\sim 65 \mathrm{~km})$ (Fig. 1) and were co-located with Coastwide Reference Monitoring Systems (CRMS) stations (http:/lacoast.gov/crms2/home.aspx). Since 2006, continuous hydrological (salinity, temperature, water level) and discrete vegetation, soil, and elevation data have been collected at the CRMS sites (Steyer et al. 2003).

\section{Collection of Soil Cores}

Soil cores were collected at the 24 sites in February 2015. The coring location was approximately $25 \mathrm{~m}$ inland from the shoreline at each site and cores were collected to a depth of $100 \mathrm{~cm}$ with a McCaulley corer (inside diameter = $5.1 \mathrm{~cm}$ ). Only the top $10 \mathrm{~cm}$ of the core was utilized for the present study. Each core was sectioned into $2-\mathrm{cm}$ depth intervals in the field, placed in whirlpaks ${ }^{\circledR}$, and stored on 


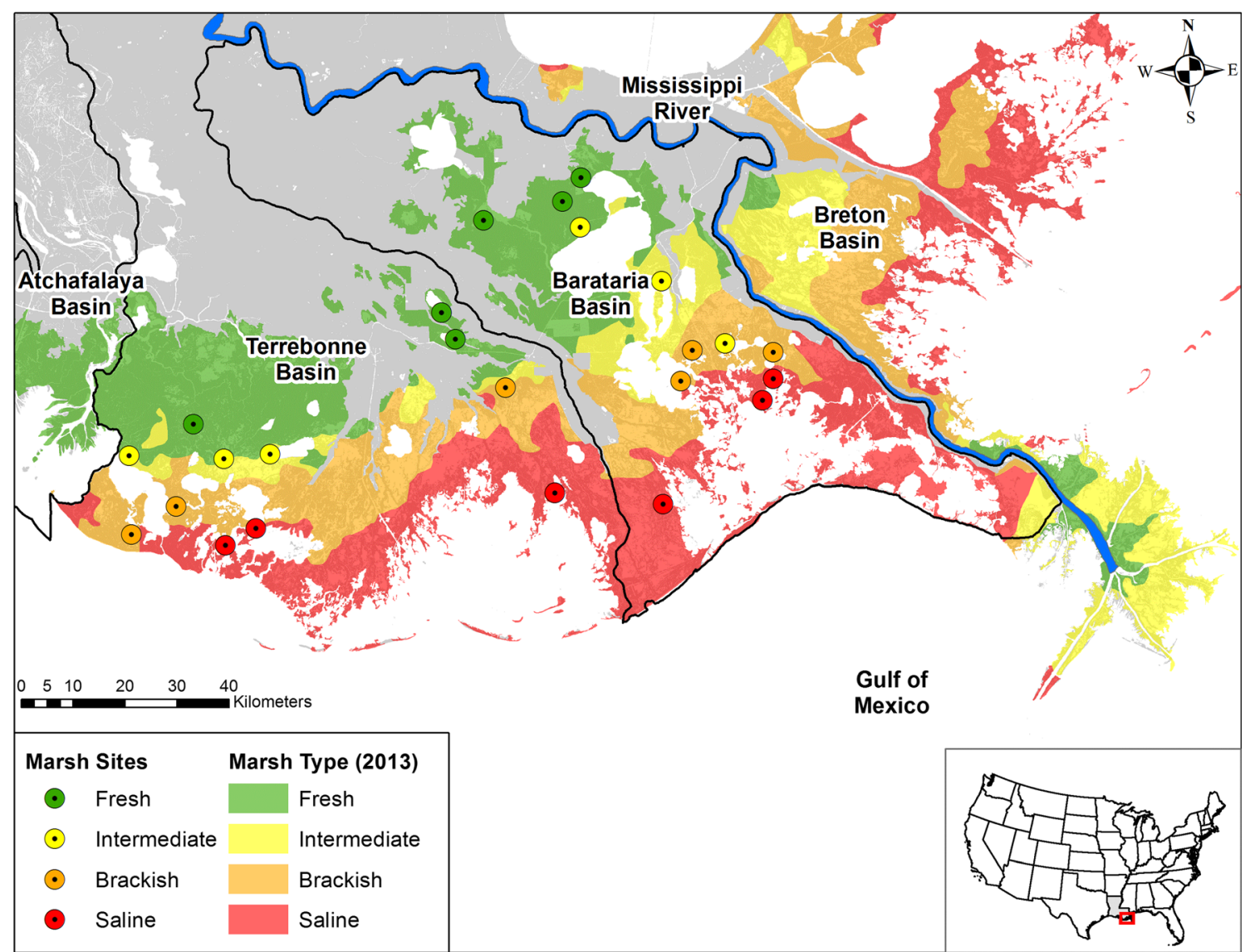

Fig. 1 Study site locations within four marsh types (fresh, intermediate, brackish and saline) of Barataria $(n=12)$ and Terrebonne basins $(n=12)$ in coastal Louisiana. Marsh type boundaries were defined using vegetation classification data from the Coastwide Reference Monitoring System

ice until transported to a laboratory for post-processing and further analysis.

\section{Organic Matter Conversion}

Soil samples from each 2-cm increment were freeze-dried to a constant weight to determine $\%$ moisture and dry bulk density and then ground using a mortar and pestle. Loss on ignition methodology was used to determine soil organic matter content and inorganic matter via combustion at $550^{\circ} \mathrm{C}$ for $14 \mathrm{~h}$ (Wilson and Allison 2008). Supplemental soil cores from a previous study (Baustian et al. unpublished data) helped to develop a conversion rate from soil organic matter to total carbon content for soil samples with these region-specific characteristics (Craft et al. 1991; Morris et al. 2016). Supplementary soil cores were collected with a PVC corer $(10.16 \mathrm{~cm}$ inner diameter, $30 \mathrm{~cm}$ long, sliced at $4 \mathrm{~cm}$ increments) at various CRMS sites in Barataria, Breton, and Atchafalaya basins. These soil samples were simultaneously analyzed for organic matter (via Loss on Ignition, Heiri et al. 2001), total organic carbon, and total carbon according to USEPA methodology 440. The total organic carbon (\%) and total carbon (mineral + organic, \%) of the soil layers collected previously in fresh to saline marsh types were significantly correlated to the soil organic matter (\%) (Fig. 2). The soil total organic carbon fraction on average contributed about $97 \%$ of the soil total carbon, therefore these parameters are near identical and both can be used to estimate carbon content. A conversion factor of 0.47 obtained from the regression coefficient of the total carbon vs. soil organic matter was applied to the mean soil organic matter values obtained at the 24 sites in this study (Fig. 1, colored circles) to provide informed estimates of carbon content. This conversion rate is similar to other studies that reported a slope of 0.45 between organic matter and organic carbon $(50 \mathrm{~cm}$ length cores including samples from forested wetlands) in coastal Louisiana (based on $n=1,142, r^{2}=0.93$, $p<0.001$ ) (Piazza et al. 2011; Steyer et al. 2012) and 0.50 between organic matter and total carbon based on $n=287$, $\left.r^{2}=0.98, p<0.01\right)$ for tidal marsh soils $(50 \mathrm{~cm}$ length cores $)$ in Connecticut and New York (Hill and Anisfeld 2015).

\section{Accretion Estimates}

To estimate short-term total carbon accumulation rates within each marsh type, accretion estimates were calculated using feldspar marker horizon data previously collected at 16 CRMS sites $(n=4$ for intermediate, $n=6$ for brackish and 


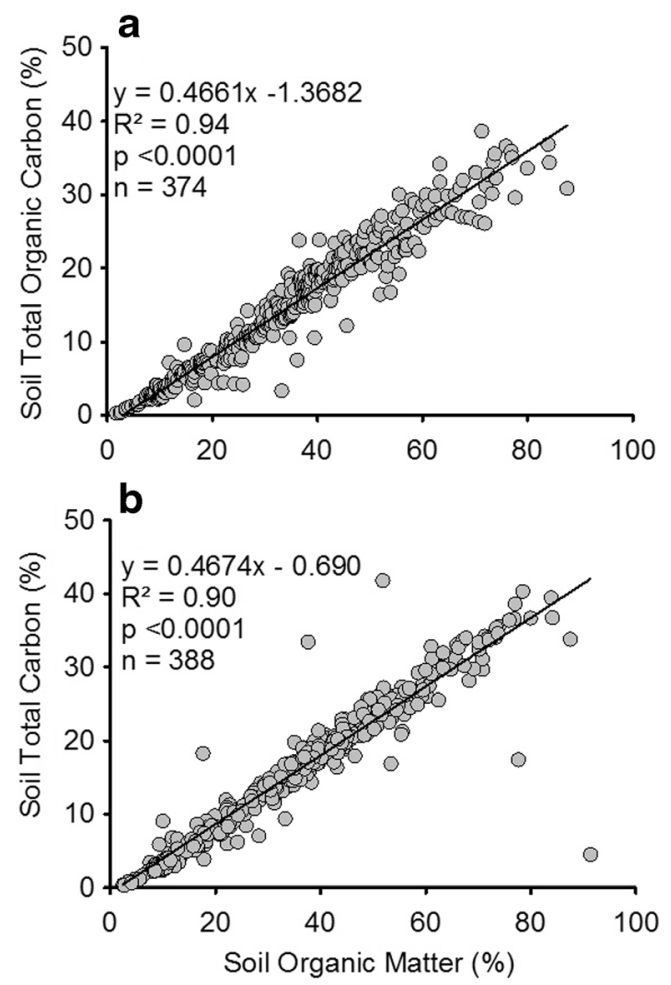

Fig. 2 Comparison of soil organic matter with (a) soil total organic carbon and (b) total carbon in soil layers $(0$ to $30 \mathrm{~cm}$ ) sampled in fresh to saline marsh types in coastal Louisiana. Total carbon content was estimated from this relationship (panel b) for calculations of short-term total carbon accumulation rates. Outliers $(n=14)$ were removed from panel $a$

$n=6$ for saline marsh types). The use of feldspar horizon markers was not recommended in the fresh marsh sites $(n=6)$ and some of the intermediate sites $(n=2)$ because they were considered floating marshes (Folse et al. 2014). The accretion measurements began in 2007 and continued through 2015 (Table 1). At each of the sites, an accretion monitoring plot was established and managed by CRMS program using a white feldspar clay as a marker horizon (Folse et al. 2014). Each plot was then sampled bi-annually for 2 years and less frequently in subsequent years (Folse et al. 2014). See other literature (Cahoon and Turner 1989; Folse et al. 2014; Bianchette et al. 2015) for more details on the feldspar methodology including limitations and benefits as well as details about downloading accretion data from the Coastal Information Management System (CIMS).

\section{Environmental Conditions}

Separate soil cores (inner diameter $=5 \mathrm{~cm}$, length $=15 \mathrm{~cm}$ ) were collected to characterize some of the environmental conditions of the marshes in December 2014. For each core, soils were homogenized, weighed, dried at $60{ }^{\circ} \mathrm{C}$, and re-weighed to determine bulk density and $\%$ moisture. A portion of the dried soil was used to measure electrical conductivity, by mixing with distilled water (1:1 slurry ratio) and analyzed using a YSI model 30 conductivity meter (Rhoades et al. 1996), organic matter, total carbon, and total nitrogen (Nelson and Sommers 1982), and total phosphorus (Aspila et al. 1976). Elevation was another environmental condition that was measured at various locations per site with a Trimble real-time kinematic (RTK) system via GEOID99. Lastly, available annual surface water salinity data between calendar years of 2000 and 2015 were used to calculate the mean annual salinity at each site (http://www.lacoast.gov/chart2 /charting.aspx?laf $=$ crms\&tab=2).

\section{Total Carbon Accumulation Estimates}

The calculation of total carbon accumulation $\left(\mathrm{g} \mathrm{TC} \mathrm{m}^{-2}\right.$ year $\left.^{-1}\right)$ in the top $10 \mathrm{~cm}$ of the soil core was determined by multiplying the carbon density $\left(\mathrm{g} \mathrm{C} \mathrm{cm}^{-3}\right)$ by the accretion rate $\left(\mathrm{cm} \mathrm{year}^{-1}\right)$ following Bernal and Mitsch $(2008 ; 2012)$ and Bianchi et al. (2013).

Coastwide salinity values were obtained from the Ecohydrology and Wetland Morphology simulation models (Meselhe et al. 2013) through publicly available output underlying the 2012 Louisiana Coastal Master Plan (Coastal Protection and Restoration Authority 2012). The model output consists of a spatial distribution of surface water salinity representing year 2010 with centroids of a $500 \times 500 \mathrm{~m}$ grid size. The salinity model outputs were used in a regression equation (with $n=16$ sites, see Fig. 6e) from this study to estimate the total carbon (g $\mathrm{TC} \mathrm{m}^{-2}$ year $^{-1}$ ) per grid cell and then multiplied by the grid size to get the total mass of carbon ( $\mathrm{g} \mathrm{TC} \mathrm{year}^{-1}$ ). The grid cells were summed across coastal Louisiana marsh area (2013 coastal marsh layer, including floating marshes, delineated by Sasser et al. (2014)) to obtain a grand total estimate in units of Tg TC year $^{-1}$. The total marsh area was estimated at $\sim 1,433,700$ ha.

\section{Statistical Analysis}

Statistical analyses and data manipulations were performed in SAS 9.4. Our null hypothesis for all tests was that there was no difference in soil properties (carbon content, bulk density, total carbon density), feldspar accretion rates, and short-term carbon accumulation rates among marsh types and slopes did not differ from zero with $\alpha=0.05$. Slopes of the time-series accretion data as well as the soil properties (\% TC and bulk density were square root transformed), feldspar accretion rates, and short-term accumulation rates versus mean annual salinity were estimated with PROC REG. Extreme outliers in the time-series accretion and mean annual salinity linear regressions were defined and identified if criteria were met by both influence techniques of DFFITS and DBETAS (Belsley et al. 1980; Aguinis et al. 2013) and were removed from further analyses. Approximately $5 \%$ of the feldspar measurements (mean value per plot set per date) were identified as outliers when regressed against time and removed prior to calculating the slopes or accretion rate estimates. Differences among marsh types were evaluated with an analysis of variance (ANOVA) using PROC GLMMIX. Exploratory analysis related 
Table 1 Field sites in various marsh types where feldspar accretion (years 2007 to 2015) and mean annual salinity (years 2010 to 2015) data were collected. Feldspar accretion estimates were not measured at fresh or intermediate floating marshes

\begin{tabular}{|c|c|c|c|c|c|c|c|c|c|c|}
\hline \multirow[b]{2}{*}{ Basin } & \multirow[b]{2}{*}{ Marsh Type } & \multirow[b]{2}{*}{$\begin{array}{l}\text { Floating } \\
\text { Type }\end{array}$} & \multirow[b]{2}{*}{ Site ID } & \multicolumn{5}{|c|}{ Feldspar Accretion Estimates } & \multicolumn{2}{|c|}{ Mean Annual Salinity } \\
\hline & & & & $\begin{array}{l}\text { No. } \\
\text { Obs. }\end{array}$ & $\begin{array}{l}\text { Begin } \\
\text { Sample Date }\end{array}$ & $\begin{array}{l}\text { End Sample } \\
\text { Date }\end{array}$ & $\mathrm{R}^{2}$ & $\begin{array}{l}\text { Feldspar Accretion rate } \\
\left(\mathrm{cm} \mathrm{year}^{-1}\right)\end{array}$ & $\begin{array}{l}\text { No. } \\
\text { Obs. }\end{array}$ & $\begin{array}{l}\text { Mean Annual } \\
\text { Salinity (ppt) }\end{array}$ \\
\hline BA & Fresh & Floating & CRMS0211 & ND & ND & ND & ND & ND & 7 & 0.20 \\
\hline BA & Fresh & Floating & CRMS0273 & ND & ND & ND & ND & ND & 10 & 0.62 \\
\hline BA & Fresh & Floating & CRMS0327 & ND & ND & ND & ND & ND & 10 & 0.61 \\
\hline $\mathrm{TE}$ & Fresh & Floating & CRMS0331 & ND & ND & ND & ND & ND & 10 & 0.29 \\
\hline TE & Fresh & Floating & CRMS0367 & ND & ND & ND & ND & ND & 10 & 0.27 \\
\hline BA & Fresh & Floating & CRMS3166 & ND & ND & ND & ND & ND & 9 & 0.25 \\
\hline BA & Intermediate & Floating & BA-01-04 & ND & ND & ND & ND & ND & 10 & 0.46 \\
\hline BA & Intermediate & Non-Floating & CRMS0225 & 21 & $11 / 6 / 2008$ & $9 / 23 / 2015$ & 0.51 & 1.78 & 10 & 5.25 \\
\hline $\mathrm{TE}$ & Intermediate & Non-Floating & CRMS0305 & 22 & $4 / 26 / 2007$ & $10 / 29 / 2015$ & 0.87 & 1.75 & 10 & 1.98 \\
\hline $\mathrm{TE}$ & Intermediate & Non-Floating & CRMS0398 & 24 & $3 / 22 / 2007$ & $10 / 23 / 2015$ & 0.82 & 1.60 & 7 & 1.95 \\
\hline TE & Intermediate & Non-Floating & CRMS4045 & 18 & $9 / 25 / 2009$ & $9 / 25 / 2015$ & 0.76 & 0.80 & 9 & 1.26 \\
\hline BA & Intermediate & Floating & CRMS4245 & ND & ND & $\mathrm{ND}$ & ND & ND & 7 & 1.67 \\
\hline BA & Brackish & Non-Floating & CRMS0253 & 23 & $4 / 5 / 2007$ & $10 / 12 / 2015$ & 0.63 & 2.25 & 10 & 4.95 \\
\hline $\mathrm{TE}$ & Brackish & Non-Floating & CRMS0309 & 22 & $4 / 26 / 2007$ & $9 / 23 / 2015$ & 0.52 & 0.64 & 10 & 9.37 \\
\hline $\mathrm{TE}$ & Brackish & Non-Floating & CRMS0399 & 20 & $4 / 26 / 2007$ & $10 / 8 / 2015$ & 0.53 & 1.10 & 10 & 5.44 \\
\hline TE & Brackish & Non-Floating & CRMS2825 & 18 & $10 / 26 / 2009$ & $10 / 29 / 2015$ & 0.43 & 1.02 & 9 & 5.42 \\
\hline BA & Brackish & Non-Floating & CRMS3565 & 24 & $4 / 16 / 2007$ & $9 / 22 / 2015$ & 0.73 & 1.64 & 5 & 4.82 \\
\hline BA & Brackish & Non-Floating & CRMS3617 & 19 & $10 / 15 / 2009$ & $9 / 14 / 2015$ & 0.41 & 0.90 & 10 & 8.08 \\
\hline BA & Saline & Non-Floating & CRMS0175 & 18 & $2 / 4 / 2009$ & $10 / 2 / 2015$ & 0.63 & 0.65 & 10 & 15.54 \\
\hline BA & Saline & Non-Floating & CRMS0224 & 20 & $5 / 5 / 2008$ & $10 / 22 / 2015$ & 0.65 & 0.34 & 10 & 9.45 \\
\hline BA & Saline & Non-Floating & CRMS0237 & 17 & $5 / 28 / 2008$ & $10 / 22 / 2015$ & 0.40 & 1.86 & 10 & 8.90 \\
\hline $\mathrm{TE}$ & Saline & Non-Floating & CRMS0337 & 19 & $10 / 21 / 2009$ & $10 / 9 / 2015$ & 0.48 & 0.54 & 10 & 18.23 \\
\hline $\mathrm{TE}$ & Saline & Non-Floating & CRMS0377 & 18 & $2 / 3 / 2009$ & $10 / 5 / 2015$ & 0.21 & 0.23 & 10 & 14.33 \\
\hline TE & Saline & Non-Floating & CRMS4455 & 15 & $2 / 3 / 2009$ & $10 / 6 / 2015$ & 0.84 & 1.01 & 10 & 9.64 \\
\hline
\end{tabular}

$B A$ Barataria, TE Terrebonne, $N D$ no data

to how the environmental conditions (represented as vectors) may vary across (represented as symbols) marsh types was conducted with a correlation biplot based on principal component analysis (PCA). A correlation matrix on standardized data and $\alpha$ decomposition of 0.5 for a symmetrical plot with the PROC PRINCOMP statement and biplot macro was used in SAS. Using R software (R Core Team 2013), we conducted an analysis of similarities (ANOSIM) to test statistically whether there was a significant difference in principal components factor scores among the four marsh types.

\section{Results}

\section{Soil Properties per Marsh Type}

The mean percent total carbon (TC) in the layers of the top $10 \mathrm{~cm}$ varied among marsh types (Fig. 3). Overall, by pooling the layers per marsh type the mean percent TC was about $32 \pm 1,17 \pm 2$, $16 \pm 1$ and $9 \pm 1 \%$ in the fresh, intermediate, brackish and saline marsh types, respectively. A mean of the top four layers per soil core was calculated to estimate the soil properties of the sites including the total carbon accumulation rate.

The mean percent TC ( \pm std. error) and bulk density among the four marsh types significantly differed $(p=0.0001$, Fig. $4 \mathrm{a}, \mathrm{b})$. The mean percent TC of the fresh marshes was highest, with intermediate and brackish types similar between each other but significantly higher than the saline marshes (Fig. 4a). Dry soil bulk density in the upper $10 \mathrm{~cm}$ ranged between 0.07 to $0.19 \mathrm{~g} \mathrm{~cm}^{-3}$ among the marsh types and compared to the percent TC the bulk density had a similar significant but opposite trend with increasing salinity of marsh types (Fig. $4 \mathrm{~b})$. The mean total carbon density $\left(\mathrm{g} \mathrm{cm}^{-3}\right)$ was higher in the fresh marsh type $(0.022 \pm 0.001, p=0.002)$ compared to the other three types: intermediate $(0.017 \pm 0.002)$, brackish $(0.015 \pm 0.001)$, and saline $(0.016 \pm 0.001)$ (Fig. $4 \mathrm{c})$. 


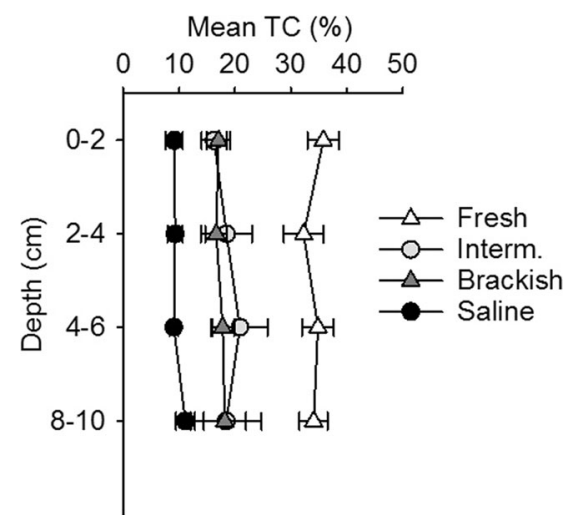

Fig. 3 Mean ( \pm std. error) total carbon content (\%) per soil layer in the top $10 \mathrm{~cm}(n=6$ per layer per marsh type) representing four marsh types, fresh, intermediate, brackish and saline in coastal Louisiana

\section{Accretion Estimates per Marsh Type}

The mean feldspar estimated accretion rates were nearly significantly different among the four marsh types ( $p=0.07$, Fig. 4d). The mean feldspar accretion rate was not available for the fresh marsh type while the intermediate marsh type was estimated at $1.71 \pm 0.05 \mathrm{~cm}^{\text {year }}{ }^{-1}$, brackish at $1.26 \pm 0.24 \mathrm{~cm}_{\text {year }}{ }^{-1}$, and saline marsh type at $0.77 \pm 0.24 \mathrm{~cm}_{\text {year }}{ }^{-1}$. Accretion rates at brackish and saline sites were highly variable (Fig. 4d).

\section{TC Accumulation Rates per Marsh Type}

The short-term TC accumulation rates ranged between 41 to $391 \mathrm{~g} \mathrm{TC} \mathrm{m}^{-2}$ year $^{-1}(n=16$, Fig. 4e). One intermediate site (CRMS 4045, $137 \mathrm{~g} \mathrm{TC} \mathrm{m}^{-2}$ year $^{-1}$ ) was identified and removed as an outlier when regressed on mean annual salinities. The short-term TC accumulation rates for the remaining sites $(n=15)$ were then used an ANOVA and these rates were not significantly different across the three marsh types $\left(\mathrm{F}_{2,12}=1.89, p=0.19\right)$. Overall, the grand mean ( \pm std. err. $)$ of the short-term TC accumulation rates used in the ANOVA $(n=15)$ was $190 \pm 27 \mathrm{~g} \mathrm{TC} \mathrm{m}^{-2}$ year $^{-1}$.

\section{Environmental Variables of Marsh Types}

The PCA (Fig. 5) indicated that the first two dimensions accounted for $88 \%$ of the variation of the field samples.

Fig. 4 Box plots of top $10 \mathrm{~cm}$ soil characteristics of (a) total carbon $(n=22$ fresh, $n=23$ intermediate, $n=24$ brackish, $n=24$ saline), (b) bulk density ( $n=23$ fresh, $n=23$ intermediate, $n=24$ brackish, $n=24$ saline), (c) total carbon density ( $n=22$ fresh, $n=23$ intermediate, $n=24$ brackish, $n=24$ saline), (d) feldspar accretion rates ( $n=0$ fresh, $n=4$ intermediate, $n=6$ brackish and $n=6$ saline) and e short-term total carbon accumulation rates ( $n=0$ fresh, $n=4$ intermediate, $n=6$ brackish, and $n=6$ saline) representing four marsh types, fresh, intermediate, brackish and saline in coastal Louisiana. Different letters indicate significant difference. The box plot dashed line $=$ mean, solid line $=$ median and whiskers above and below the box indicate the 90th and 10th percentiles. ND = no data
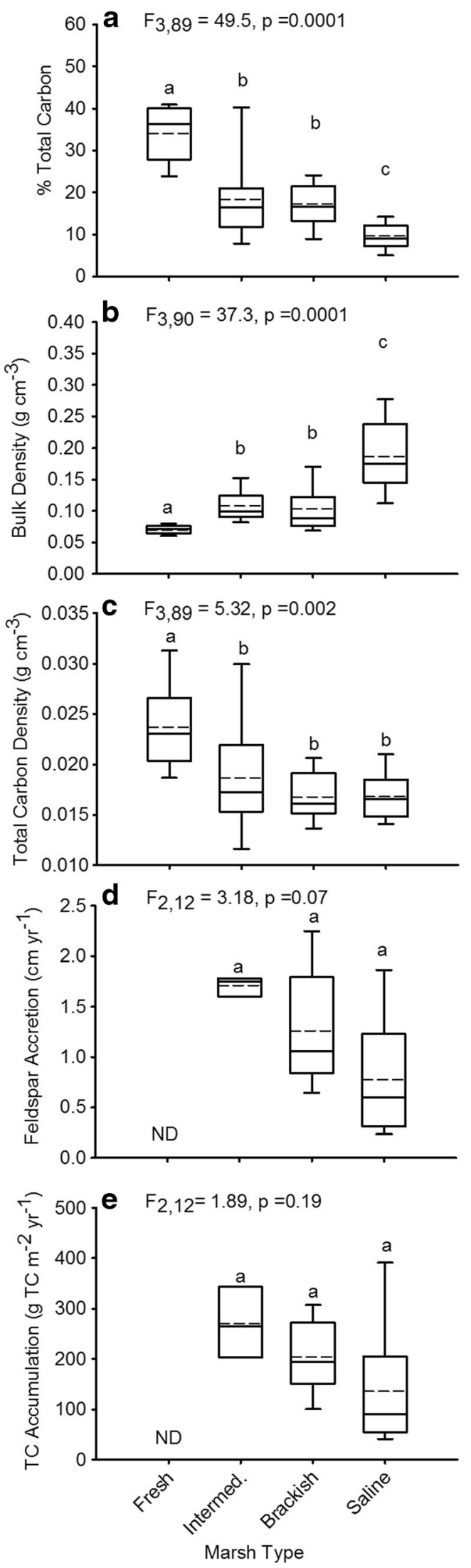
From the PCA biplot (Fig. 5), it was observed that the field sites tended to cluster into their respective four marsh types irrespective of their basin location with fresh sites on the far right and saline sites on the far left leaving the intermediate and brackish sites intermixed in the middle. The soil properties of organic matter, total carbon, total phosphorus, and total nitrogen had high positive correlation (i.e., small angles between vectors) among each other. For PC1, the compositional dissimilarities among the four wetland types were greater than those within the wetland types, indicating that there was a significant separation of $\mathrm{PC} 1$ parameters among the four wetland types $(R=0.22, p=0.002)$. High bulk density and electrical conductivity of the soils as well as the mean annual salinity of the surface waters were positively correlated with the saline marsh sites. Elevation seemed to be uncorrelated with the other soil properties. The saline marsh sites had the lowest concentrations of the soil properties of $\% \mathrm{TN}, \% \mathrm{TC}$ and $\% \mathrm{TP}$ (i.e., furthest location from the variable).

The soil properties and short-term TC accumulation rates were all significantly related to the mean annual salinities (years 2000 to 2015) of the marsh sites (Fig. 6). The \% total carbon, total carbon density, and feldspar accretion rates all had significant negative relationships with mean annual salinity (Fig. 6a, c, d). Bulk density was the only soil property that had a positive relationship (Fig. 6b). Mean annual salinity was negatively correlated with the TC accumulation rates (Fig. 6e) and accounted for about $40 \%$ of the variation of the short-term TC accumulation rates $\left(R^{2}=0.40, p=0.01, n=15\right)$.

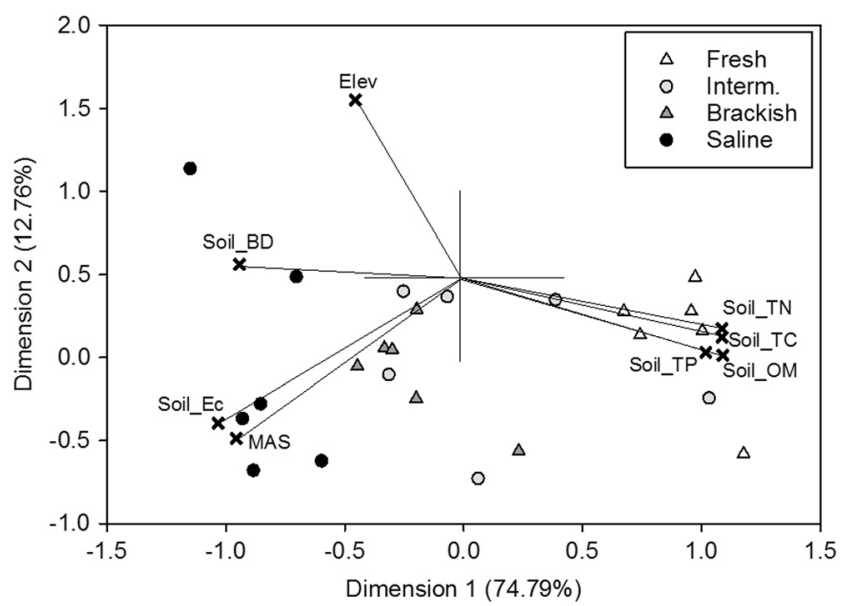

Fig. 5 Principal component analysis (PCA) biplot of soil and surface water variables as vectors $(n=8)$ and marsh sites as points color coded per marsh type $(n=24)$. The soil variables included total carbon (soil TC), organic matter (soil OM), bulk density (soil BD), total phosphorus (soil_TP), total nitrogen (soil_TN), electroconductivity (soil_Ec), and elevation (Elev). The surface water variable included the mean annual salinity (years 2000-2015, MAS). Perpendicular vectors are uncorrelated, vectors with small angles between them are positively correlated and opposite vectors are negatively correlated. Longer lengths of vectors indicate higher variability

\section{Coastwide Estimate of Short-Term Carbon Pool}

The total short-term carbon pool of fresh, intermediate, brackish and saline marshes in coastal Louisiana was estimated based on two approaches, the mean annual salinity and short-term TC accumulation regression equation (see Fig. 6e) and the mean value when comparing the marsh types provides a global context on the amount of marsh soil carbon coastal Louisiana contributes. Based on previously modeled salinity output and the regression equation, the coastal marshes on the central and western region tend to have the highest short-term TC accumulation rates with the eastern area having the lowest and overall the marshes store about $3.3 \mathrm{Tg} \mathrm{TC}$ year $^{-1}$ (Fig. 7). By using the mean value of short-term carbon accumulation rate from comparing the marsh types and the estimated area of marsh in coastal Louisiana $(\sim 1,433,700 \mathrm{ha})$ these marshes were estimated to store in the short term about $2.7 \mathrm{Tg} \mathrm{TC}$ year $^{-1}$.

\section{Discussion}

\section{Short-Term TC Accumulation Rates}

Significant declines in short-term carbon accumulation with increasing salinity were found when rates were regressed against mean annual salinity of surface waters; however, categorical analysis of short-term carbon accumulation rates showed no significant differences among marsh types, reflecting the high variability of short-term total carbon accumulation within marsh types (fresh, intermediate, brackish and saline). This pattern was also observed with the feldspar accretion rates. Given the regression results, it is clear that salinity, per se, is an important predictor of short-term carbon accumulation rates (Craft 2007). However, because marsh types are not exclusively defined by salinity, analysis of variance among marsh types allows us to identify potential mechanisms associated with marsh type that are not directly related to salinity or may not be explicitly defined in a regression analysis. Therefore, we considered patterns across the salinity gradient as well as among different marsh types. For example, the separation of the marsh sites along the Dimension 1 axis of the PCA helps generalize characteristics about the marsh types. The fresh marshes had higher soil carbon, nitrogen and phosphorus, while the saline marshes had higher bulk density, soil and surface water salinities. As expected, the intermediate and brackish sites had values in between those end members. The fresh marsh sites, with their associated higher soil carbon content, may be associated with higher primary production and perhaps higher short-term carbon accumulation rates. Alternatively, decomposition rates may be slower in the 

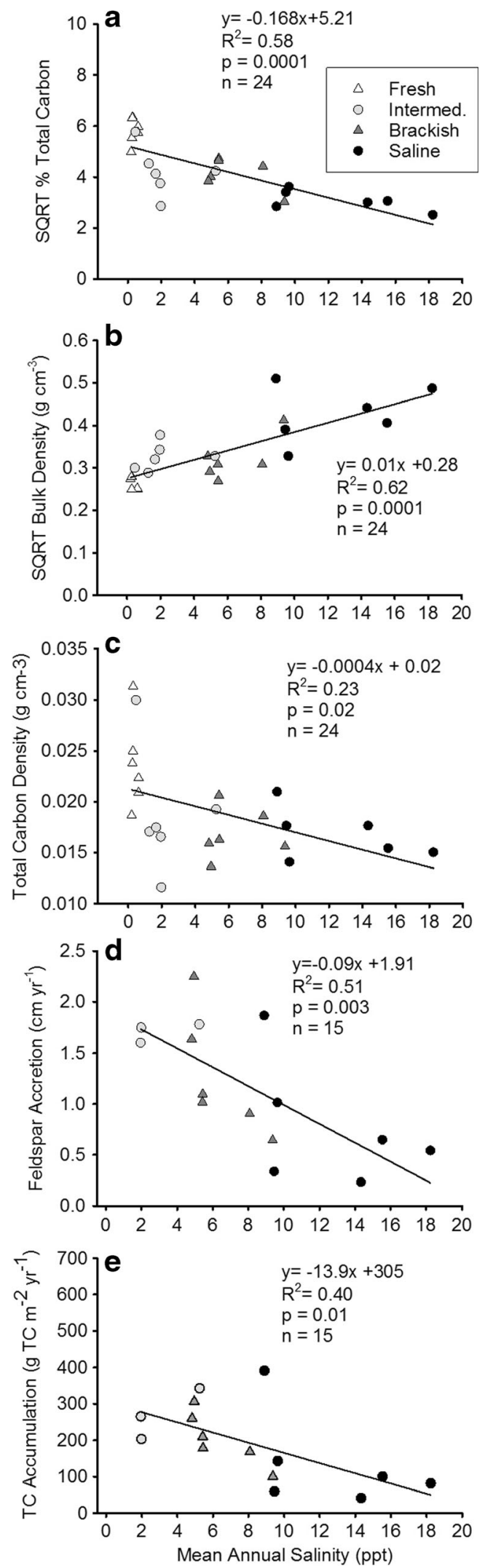

fresher sites compared to the more saline sites, as mentioned previously and supported by Williams and Rosenheim (2015).
Fig. 6 Soil properties (a to c), feldspar accretion rates (d) and short-term total carbon (TC) accumulation rates (e) in relation to mean annual salinity within four marsh types, fresh (open triangle), intermediate (light grey filled circle), brackish (dark grey filled triangle) and saline (black filled circle)

Estimates of production and decomposition of organic matter both above and belowground within these four marsh types would help to better explain the net effect that produces these short-term carbon accumulation rates (Neubauer 2008).

Short-term TC accumulation rates from the Gulf region integrated over the top $10-15 \mathrm{~cm}$ of the soil cores were reported by Hansen and Nestlerode (2014) using ${ }^{137} \mathrm{Cs}$ based estimates of accretion. They found the brackish marshes dominated by $S$. patens had short-term TC accumulation rates of $290 \pm 170.3 \mathrm{~g} \mathrm{TC} \mathrm{m}^{-2}$ year $^{-1}$, salt marshes in Louisiana had $329 \pm 217 \mathrm{~g} \mathrm{TC} \mathrm{m}^{-2}$ year $^{-1}$ and salt marshes outside of Louisiana as $173 \pm 131 \mathrm{~g}$ TC $\mathrm{m}^{-2}$ year $^{-1}$. They also reported similar mean accretion rates $0.72,0.94$ and $0.57 \mathrm{~cm}_{\text {year }}{ }^{-1}$ respectively across the three marsh types in their study (Hansen and Nestlerode 2014). Overall, these mean accretion rates and TC accumulation rates are within the range of this study, but brackish marshes in the current study had accretion rates $\left(1.26 \mathrm{~cm} \mathrm{year}^{-1}\right)$ that exceed Hansen and Nestlerode (2014) estimates $\left(0.72 \mathrm{~cm} \mathrm{year}^{-1}\right)$, and the saline marshes were similar (current study $=$ $0.77 \mathrm{~cm} \mathrm{year}^{-1}$, Hansen and Nestlerode (2014) = $\left.0.94 \mathrm{~cm} \mathrm{year}^{-1}\right)$. However, in this study saline marsh types had lower mean short-term TC accumulation rates $\left(\sim 135 \mathrm{~g} \mathrm{TC} \mathrm{m}^{-2}\right.$ year $\left.^{-1}\right)$ compared to Hansen and Nestlerode (2014) reported rates, which is likely because their mean bulk density values (an essential variable for calculating accumulation) for Louisiana salt marshes were twice as high as the marshes sampled in this study (current study $=0.19 \mathrm{~g} \mathrm{~cm}^{-3}$, Hansen and Nestlerode $\left.(2014)=0.4 \mathrm{~g} \mathrm{~cm}^{-3}\right)$. The differences in bulk density could be due to spatial variation within the marsh, for example marsh edge $\left(0.35 \mathrm{~g} \mathrm{~cm}^{-3}\right)$ versus interior $\left(0.29 \mathrm{~g} \mathrm{~cm}^{-3}\right)$ as observed in another study (Hatton et al. 1983). In addition, the use of ${ }^{137} \mathrm{Cs}$ versus feldspar to estimate short-term carbon accumulation rates could also be adding to the variability in results among these two studies.

Short-term total carbon accumulation rates calculated from feldspar methodology from various marsh types along a landscape gradient are not readily available. This study provides a novel contribution to the growing body of literature on carbon accumulation rates in wetlands by providing insight on how short-term processes (net effect from production, decomposition, bioturbation, etc.) captured in these accumulation rates vary across the coastal landscape, which in turn will likely influence the quality and quantity of carbon being accumulated for the long-term. 


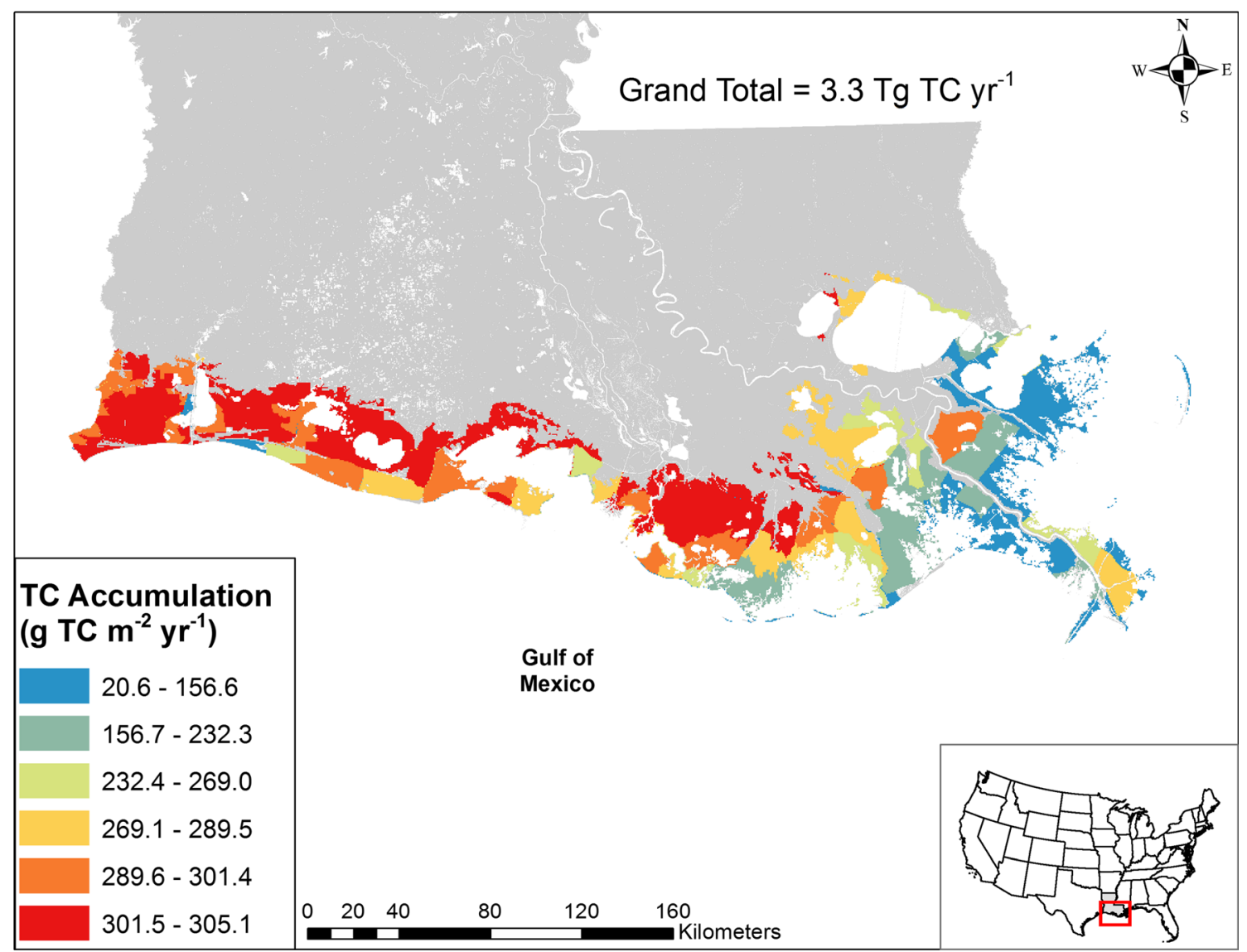

Fig. 7 Map of short-term TC accumulation rate estimates in the marshes of coastal Louisiana, USA, based on previously modeled spatial salinity output and regression analysis (see Fig. 6e). Grand total of short-term

\section{Environmental Influences on Short-Term TC Accumulation Rates}

Variation in environmental drivers may help to explain the high variation in TC accumulation rates. Williams and Rosenheim (2015) found, in agreement with this study, that the total organic carbon content (in these soils total carbon percentages are similar) varied significantly among fresh, brackish and saline marshes in Barataria Basin, Louisiana, with fresh marsh soils containing the highest total organic carbon content (\%). They also found from pyrolysis methodology that organic carbon in fresh marsh soils tended to be most stable, or least degradable, among the marsh types and attributed this to a decrease in remineralization due to high water content of the soils and higher recalcitrance of soil organic matter. This study also found a negative relationship between salinity and short-term TC accumulation rates, and $\sim 40 \%$ of the variation of the short-term TC accumulation rates was explained by the mean annual salinity from years 2000 to 2015. Craft (2007) and Neubauer (2008) reported negative correlations between vertical accretion rates, which influence short-term TC accumulation rates, and salinity. They suggest that freshwater has positive effects on organic matter carbon pool for the entire marsh area of coastal Louisiana is listed. Marsh type comparison approach suggested a lower grand total of short-term carbon pool of $2.7 \mathrm{Tg}$ TC year $^{-1}$

production and preservation while saline water stimulated root decomposition resulting in lower rates of organic matter accumulation. Seawater sulfate plays a critical role in regulating decomposition and productivity by enhancing decomposition via sulfate reduction, a process which also generates sulfides that are toxic to plants (Neubauer and Craft 2009).

\section{Coastwide TC Short-Term Accumulation}

The fresh, intermediate, brackish and saline marshes of coastal Louisiana overall accumulate between 2.7 to $3.3 \mathrm{Tg} \mathrm{C}$ year ${ }^{-1}$. This regional value alone comprises a notable fraction $(\sim 5-$ $60 \%$ ) of global estimates of carbon accumulation of salt marshes (5-87 Tg C year ${ }^{-1}$ ) (Chmura et al. 2003; McLeod et al. 2011) and emphasizes the important role that coastal and deltaic wetlands play in the global carbon cycle. In addition, Mcleod et al. (2011) used an average salt marsh accumulation rate of $218 \pm 24 \mathrm{~g} \mathrm{TC} \mathrm{m}^{-2}$ year $^{-1}$ to calculate their global accumulation estimates, similar to the current mean estimate across the three marsh types $\left(190 \pm 27 \mathrm{~g} \mathrm{TC} \mathrm{m}^{-2}\right.$ year $^{-1}$, $n=15$ ). However, it should be noted that the global estimates of areal extent of salt marshes is not well constrained and likely drives the high variability in the global burial estimates 
(Chmura 2013). Better estimates on areal extent of these marshes would help to refine global carbon budget estimates. These comparisons suggest that, not only do salt marshes play an important role in carbon accumulation and burial, but also, global estimates of carbon accumulation that do not consider salinity changes across coastal landscape gradients may not be accurate. Furthermore, if these marshes transition to more saline marshes due to climate change, or towards fresh marshes due to large scale restoration actions, the short-term global carbon pool may change. Balancing the greenhouse gas emissions from each of these four marsh types with the short-term carbon accumulation rates may provide a comprehensive understanding of the role of these marshes in overall carbon sequestration (Poffenbarger et al. 2011; Holm et al. 2016; Krauss et al. 2016). For example, fresh marshes may accumulate a large amount of carbon, but they produce methane gas during anaeraboic metabolism, which has a global warming potential that is 25 times greater than carbon dioxide (Whiting and Chanton 2001).

Short-term total carbon accumulation estimates from marsh types that span a salinity gradient illustrate potential implications for ecological responses to sea-level rise and coastal restoration. If surface waters become more saline due to sealevel rise or freshwater limitations, coastal wetlands may transition to a more salt-tolerant plant communities and accumulate less total carbon in their soils (Williams and Rosenheim 2015; Herbert et al. 2015). Conversely, if more freshwater reaches the coast via riverine discharge, restoration management actions such as large river diversions, or increased precipitation events, coastal wetlands may become fresher and accumulate more soil carbon in the short term (Morris et al. 2013). These results also may help guide where along the salinity gradient to place marsh restoration and creation projects to maximize short-term carbon accumulation capacities and potential carbon credits.

\footnotetext{
Acknowledgements This project was supported by the Science and Engineering Program of The Water Institute of the Gulf with funds from the Louisiana Coastal Protection and Restoration Authority (CPRA) and the Baton Rouge Area Foundation (BRAF) as well as U.S. Geological Survey Ecosystems Program, and Restore the Mississippi River Delta Campaign via Coalition to Restore Coastal Louisiana (CRCL). Many helping hands assisted in retrieving and processing the soil samples. We thank the following researchers at the USGS Wetland and Aquatic Research Center: Ada Diaz, Alyssa Mitchell, Brett Patton, Courtney Lee, Evan Bergeron, Jacy Reynolds, Lindsey Hebert, Sarai Piazza and Rachel Villani. In addition, Caitlin Pinsonat from the Water Institute of the Gulf assisted in field and laboratory work. Jackson Rollings helped CRCL through AmeriCorps' Louisiana Delta Service Corps Program in field data collection. Special thanks to Diana Di Leonardo and Amanda Cuesta at Tulane University for assisting in soil organic matter laboratory analyses and to Ioannis Georgiou at University of New Orleans for letting us borrow the corer. Lastly, thank you to the three anonymous reviewers that provided excellent comments that helped strengthen our paper.
}

Open Access This article is distributed under the terms of the Creative Commons Attribution 4.0 International License (http:// creativecommons.org/licenses/by/4.0/), which permits unrestricted use, distribution, and reproduction in any medium, provided you give appropriate credit to the original author(s) and the source, provide a link to the Creative Commons license, and indicate if changes were made.

\section{References}

Aguinis H, Gottfredson RK, Joo H (2013) Best-practice recommendations for defining, identifying, and handling outliers. Organizational Research Methods 16:270-301. doi:10.1177/1094428112470848

Aspila KI, Agemian H, Chau ASY (1976) A semi-automated method for the determination of inorganic, organic and total phosphate in sediments. Analyst 101:187-197. doi:10.1039/AN9760100187

Baustian JJ, Mendelssohn IA, Hester MW (2012) Vegetation's importance in regulating surface elevation in a coastal salt marsh facing elevated rates of sea level rise. Global Change Biology 18:33773382. doi:10.1111/j.1365-2486.2012.02792.x

Belsley DA, Kuh E, Welsch RE (1980) Regression diagnostics: Identifying influential data and sources of collinearity. John Wiley \& Sons, Inc

Bernal B, Mitsch WJ (2008) A comparison of soil carbon pools and profiles in wetlands in Costa Rica and Ohio. Ecological Engineering 34:311-323. doi:10.1016/j.ecoleng.2008.09.005

Bernal B, Mitsch WJ (2012) Comparing carbon sequestration in temperate freshwater wetland communities. Global Change Biology 18: 1636-1647. doi:10.1111/j.1365-2486.2011.02619.x

Bianchette T, Liu K, Qiang Y, Lam N (2015) Wetland accretion rates along coastal Louisiana: spatial and temporal variability in light of Hurricane Isaac's impacts. Water 8:1. doi:10.3390/w8010001

Bianchi TS, Allison MA, Zhao J et al (2013) Historical reconstruction of mangrove expansion in the Gulf of Mexico: Linking climate change with carbon sequestration in coastal wetlands. Estuarine, Coastal and Shelf Science 119:7-16. doi:10.1016/j.ecss.2012.12.007

Cahoon DR, Turner RE (1989) Accretion and canal impacts in a rapidly subsiding wetland II. Feldspar marker horizon technique. Estuaries $12: 260-268$

Callaway JC, Borgnis EL, Turner RE, Milan CS (2012) Carbon sequestration and sediment accretion in San Francisco Bay tidal wetlands. Estuaries and Coasts 35:1163-1181. doi:10.1007/s12237-012-9508-9

Callaway JC, Nyman JA, DeLaune RD (1996) Sediment accretion in coastal wetlands: a review and a simulation model of processes. Current Topics in Wetland Biogeochemistry 2:2-23

Chabreck RH (1972) Vegetation, water, and soil characteristics of the Louisiana coastal region. Louisiana State University Agricultural Experiment Station. Bulletin No. 664. Baton Rouge, LA

Chmura GL (2013) What do we need to assess the sustainability of the tidal salt marsh carbon sink? Ocean and Coastal Management 83: 25-31. doi:10.1016/j.ocecoaman.2011.09.006

Chmura GL, Anisfeld SC, Cahoon DR, Lynch JC (2003) Global carbon sequestration in tidal, saline wetland soils. Global Biogeochemical Cycles 17:1111. doi:10.1029/2002GB001917

Coastal Protection and Restoration Authority (2012) Louisiana's 2012 Coastal Master Plan | Committed to our Coast. p 189

Comeaux RS, Allison MA, Bianchi TS (2012) Mangrove expansion in the Gulf of Mexico with climate change: Implications for wetland health and resistance to rising sea levels. Estuarine, Coastal and Shelf Science 96:81-95. doi:10.1016/j.ecss.2011.10.003

Couvillion BR, Steyer GD, Wang H et al (2013) Forecasting the effects of coastal protection and restoration projects on wetland morphology 
in coastal Louisiana under multiple environmental uncertainty scenarios. Journal of Coastal Research 67:29-50. doi:10.2112/SI_67_3

Cowardin LM, Carter V, Golet FC, LaRoe ET (1979) Classification of wetlands and deepwater habitats of the United States. Fish and Wildlife Service, US Department of the Interior Washington, DC

Craft C (2007) Freshwater input structures soil properties, vertical accretion, and nutrient accumulation of Georgia and U.S tidal marshes. Limnology and Oceanography 52:1220-1230. doi: $10.4319 / 10.2007 .52 .3 .1220$

Craft C, Broome S, Campbell C (2002) Fifteen years of vegetation and soil development after brackish-water marsh creation. Restoration Ecology 10:248-258. doi:10.1046/j.1526-100X.2002.01020.x

Craft CB, Clough J, Ehman J et al (2009) Forecasting the effects of accelerated sea-level rise on tidal marsh ecosystem services. Frontiers in Ecology and the Environment 7:73-78. doi:10.1890/070219

Craft CB, Seneca ED, Broome SW (1991) Loss on ignition and Kjeldahl digestion for estimating organic carbon and total nitrogen in estuarine marsh soils: calibration with dry combustion. Estuaries 14:175. doi: $10.2307 / 1351691$

De Deyn GB, Cornelissen JHC, Bardgett RD (2008) Plant functional traits and soil carbon sequestration in contrasting biomes. Ecology Letters 11:516-531. doi:10.1111/j.1461-0248.2008.01164.x

Delaune RD, Patrick WH, Buresh RJ (1978) Sedimentation rates determined by ${ }^{137} \mathrm{Cs}$ dating in a rapidly accreting salt marsh. Nature 275 : 532-533. doi:10.1038/275532a0

Doughty CL, Langley JA, Walker WS et al (2015) Mangrove range expansion rapidly increases coastal wetland carbon storage. Estuaries and Coasts. doi:10.1007/s12237-015-9993-8

Folse TM, West JL, Hymel MK, et al (2014) A Standard Operating Procedures Manual for the Coast-wide Reference Monitoring System - Wetlands: Methods for Site Establishment, Data Collection, and Quality Assurance/Quality Control. Coastal Protection and Restoration Authority. Baton Rouge, LA. p 228

Gallagher JL, Wolf PL, Pfeiffer WJ (1984) Rhizome and root growth rates and cycles in protein and carbohydrate concentrations in Georgia Spartina alterniflora Loisel. plants. American Journal of Botany 71:165-169. doi:10.2307/2443742

Hansen V, Nestlerode J (2014) Carbon sequestration in wetland soils of the northern Gulf of Mexico coastal region. Wetlands Ecology and Management 22:289-303. doi:10.1007/s11273-013-9330-6

Hatton RS, DeLaune RD, Patrick WH (1983) Sedimentation, accretion, and subsidence in marshes of Barataria Basin, Louisiana. Limnology and Oceanography 28:494-502. doi:10.4319/1o.1983.28.3.0494

Heiri O, Lotter AF, Lemcke G (2001) Loss on ignition as a method for estimating organic and carbonate content in sediments: reproducibility and comparability of results. Journal of Paleolimnology 25:101110. doi:10.1023/A:1008119611481

Herbert ER, Boon P, Burgin AJ et al (2015) A global perspective on wetland salinization: ecological consequences of a growing threat to freshwater wetlands. Ecosphere 6:1-43. doi:10.1890/ES14-00534.1

Hill TD, Anisfeld SC (2015) Coastal wetland response to sea level rise in Connecticut and New York. Estuarine, Coastal and Shelf Science 163:185-193. doi:10.1016/j.ecss.2015.06.004

Holm GO, Perez BC, McWhorter DE et al (2016) Ecosystem level methane fluxes from tidal freshwater and brackish marshes of the Mississippi river delta: implications for coastal wetland carbon projects. Wetlands. doi:10.1007/s13157-016-0746-7

Hopkinson CS, Cai W-J, Hu X (2012) Carbon sequestration in wetland dominated coastal systems - a global sink of rapidly diminishing magnitude. Current Opinion in Environmental Sustainability 4:186194. doi:10.1016/j.cosust.2012.03.005
Kirwan ML, Temmerman S, Skeehan EE et al (2016) Overestimation of marsh vulnerability to sea level rise. Nature Climate Change 6:253260. doi:10.1038/nclimate2909

Krauss KW, Holm GO, Perez BC et al (2016) Component greenhouse gas fluxes and radiative balance from two deltaic marshes in Louisiana: pairing chamber techniques and eddy covariance. Journal of Geophysical Research Biogeosciences 121:1503-1521. doi:10.1002/2015JG003224

Marín-Spiotta E, Gruley KE, Crawford J et al (2014) Paradigm shifts in soil organic matter research affect interpretations of aquatic carbon cycling: transcending disciplinary and ecosystem boundaries. Biogeochemistry 117:279-297. doi:10.1007/s10533-013-9949-7

Markewich HW, Buell GR, Britsch LD, et al. (2007) Organic-carbon sequestration in soil/sediment of the Mississippi River deltaic plain - data; landscape distribution, storage, and inventory; accumulation rates; and recent loss, including a post-Katrina preliminary analysis. Soil - carbon storage and inventory for the Continental United States. U.S. Geological Survey, Reston, Virginia, p 257

McLeod E, Chmura GL, Bouillon S et al (2011) A blueprint for blue carbon: toward an improved understanding of the role of vegetated coastal habitats in sequestering $\mathrm{CO}_{2}$. Frontiers in Ecology and the Environment 9:552-560

Meselhe E, McCorquodale JA, Shelden J et al (2013) Ecohydrology component of Louisiana's 2012 Coastal Master Plan: Massbalance compartment model. Journal of Coastal Research 67:1628. doi:10.2112/SI $67 \quad 2.1$

Mitra S, Wassmann R, Vlek PLG (2005) An appraisal of global wetland area and its organic carbon stock. Current Science 88:25-35

Morris JT, Barber DC, Callaway JC et al (2016) Contributions of organic and inorganic matter to sediment volume and accretion in tidal wetlands at steady state. Earth's Future 4:110 121. doi:10.1002/2015EF000334

Morris JT, Bradley PM (1999) Effects of nutrient loading on the carbon balance of coastal wetland sediments. Limnology and Oceanography 44:699-702. doi:10.4319/1o.1999.44.3.0699

Morris JT, Shaffer GP, Nyman JA (2013) Brinson Review: Perspectives on the influence of nutrients on the sustainability of coastal wetlands. Wetlands 33:975-988. doi:10.1007/s13157-013-0480-3

Morris JT, Sundareshwar PV, Nietch CT et al (2002) Responses of coastal wetlands to rising sea level. Ecology 83:2869-2877

Nellemann C, Corcoran E (2009) Blue carbon: The role of healthy oceans in binding carbon: A rapid response assessment. UNEP/Earthprint

Nelson DW, Sommers LE (1982) Total carbon, organic carbon, and organic matter. In: Page AL (ed) Methods of Soil Analysis. Part 2. Chemical and Microbiological Properties. Soil Science Society of America, Madison, WI, pp 539-579

Neubauer SC (2008) Contributions of mineral and organic components to tidal freshwater marsh accretion. Estuarine, Coastal and Shelf Science 78:78-88. doi:10.1016/j.ecss.2007.11.011

Neubauer SC, Craft C (2009) Global change and tidal freshwater wetlands: scenarios and impacts. In: Barendregt $\mathrm{A}$, Whigham D, Baldwin A (eds) Tidal Freshwater Wetlands. Backhuys Publishers, Leiden, pp 253-266

Nyman JA, Walters RJ, Delaune RD, Patrick WH Jr (2006) Marsh vertical accretion via vegetative growth. Estuarine, Coastal and Shelf Science 69:370-380. doi:10.1016/j.ecss.2006.05.041

Odum WE (1984) Dual-gradient concept of detritus transport and processing in estuaries. Bulletin of Marine Science 35:510-521

Odum WE, Smith III TJ, Hoover JK, McIcor CC (1984) The ecology of tidal freshwater marshes of the United States east coast: a community profile. $\mathrm{p} 186$

Osland MJ, Spivak AC, Nestlerode JA et al (2012) Ecosystem development after mangrove wetland creation: Plant-soil change across a 20-years chronosequence. Ecosystems 15: 848-866. doi:10.1007/s10021-012-9551-1 
Piazza SC, Steyer GD, Cretini KF, et al. (2011) Geomorphic and ecological effects of Hurricanes Katrina and Rita on coastal Louisiana marsh communities. $p 126$

Poffenbarger HJ, Needelman BA, Megonigal JP (2011) Salinity influence on methane emissions from tidal marshes. Wetlands 31:831-842. doi:10.1007/s13157-011-0197-0

R Core Team (2013) R: A language and environment for statistical computing. R Foundation for Statistical Computing, Vienna, Austria

Reed DJ (1995) The response of coastal marshes to sea-level rise: survival or submergence? Earth Surface Processes and Landforms 20:39-48. doi:10.1002/esp.3290200105

Rhoades JD, Sparks DL, Page AL et al (1996) Salinity: Electrical conductivity and total dissolved solids. In: Sparks DL, Page AL, Helmke PA, Loeppert RH (eds) Methods of Soil Analysis. Part 3Chemical Methods. Soil Science Society of America, American Society of Agronomy, Madison, WI, pp 417-435

Roulet NT (2000) Peatlands, carbon storage, greenhouse gases, and the Kyoto protocol: prospects and significance for Canada. Wetlands 20:605-615

Sasser CE, Visser JM, Mouton E et al (2014) Vegetation types in coastal Louisiana in 2013. U.S. Geological Survey, Reston, Virginia

Stagg CL, Schoolmaster DR, Piazza SC, Snedden G, Steyer GD, Fischenich CJ, McComas RW (2016) A landscape-scale assessment of above- and belowground primary production in coastal wetlands: implications for climate change-induced community shifts. Estuaries and Coasts. 1-24. doi:10.1007/s12237-016-0177-y

Steyer G, Couvillion B, Wang H et al (2012) Appendix D2 - Wetland morphology model technical report. Louisiana's Comprehensive Master Plan for a Sustainable Coast. Coastal Protection and Restoration Authority, Baton Rouge, LA, p 108

Steyer GD, Sasser CE, Visser JM, Swenson EM, Nyman JA, Raynie RC (2003) A proposed coast-wide reference monitoring system for evaluating wetland restoration trajectories in Louisiana. Environmental Monitoring and Assessment 81:107-117

Taylor A, Blake WH, Smith HG et al (2013) Assumptions and challenges in the use of fallout beryllium-7 as a soil and sediment tracer in river basins. Earth-Science Reviews 126 : 85-95. doi:10.1016/j.earscirev.2013.08.002

Turner RE (2004) Coastal wetland subsidence arising from local hydrologic manipulations. Estuaries 27:265-272. doi:10.1007 /BF02803383

Turner RE, Milan CS, Swenson EM (2006) Recent volumetric changes in salt marsh soils. Estuarine, Coastal and Shelf Science 69:352-359. doi:10.1016/j.ecss.2006.05.005

Valiela I, Teal JM, Persson NY (1976) Production and dynamics of experimentally enriched salt marsh vegetation: belowground biomass. Limnology and Oceanography 21:245-252

Visser JM, Sasser CE, Chabreck RH, Linscombe RG (1998) Marsh vegetation types of the Mississippi River Deltaic Plain. Estuaries 21: $818-828$

Visser JM, Sasser CE, Chabreck RH, Linscombe, RG (2002) The impact of a severe drought on the vegetation of a subtropical estuary. Estuaries 25:1184-1195. doi:10.1007/BF02692215

Whiting GJ, Chanton JP (2001) Greenhouse carbon balance of wetlands: methane emission versus carbon sequestration. Tellus Series B: Chemical and Physical Meteorology 53: 521-528. doi:10.1034/j.1600-0889.2001.530501.x

Williams EK, Rosenheim BE (2015) What happens to soil organic carbon as coastal marsh ecosystems change in response to increasing salinity? An exploration using ramped pyrolysis: Fate of coastal SOC with salinity. Geochemistry, Geophysics, Geosystems 16:23222335. doi:10.1002/2015GC005839

Wilson CA, Allison MA (2008) An equilibrium profile model for retreating marsh shorelines in southeast Louisiana. Estuarine, Coastal and Shelf Science 80:483-494. doi:10.1016/j.ecss.2008.09.004 